\title{
Effects of Preschool Education in Preparing Children for the First Grade in Terms of Linguistic and Mathematical Development
}

\author{
Majlinda Gjelaj \\ Faculty of Philosophy, Department of Pedagogy, University of Pristina, Pristina, Kosovo \\ Email: gjelajmajlinda@gmail.com
}

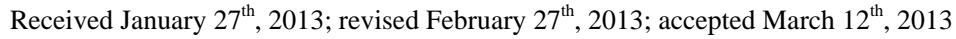

\begin{abstract}
Copyright ( 2013 Majlinda Gjelaj. This is an open access article distributed under the Creative Commons Attribution License, which permits unrestricted use, distribution, and reproduction in any medium, provided the original work is properly cited.
\end{abstract}

\begin{abstract}
The purpose of this research is to determine the level of children's readiness for the first grade, in terms of mathematical and linguistic development. This research is quantitative and includes 466 children who were enrolled in the first grade in September 2011, as well as their parents. They belong to various schools in towns and villages of Kosovo. The sample was randomly selected. Children are assessed for their intellectual readiness, separately in mathematical and linguistic development through standardized measuring instrument by the "Brainline" author Joey Du Plooy. The questionnaire was translated and adapted. In this paper it will be focused only mathematical and linguistic development of children who have just started the first grade. Children are evaluated by a team of pedagogy who have been previously trained in the use of this questionnaire. Each child is individually assessed and the questions that were impossible to take from the children are taken from their parents. The survey results raise awareness about the importance of preschool institutionalized education and provide advices of the importance of preparing children for starting the first grade without fear and with self-esteem.
\end{abstract}

Keywords: Preschool Education; School Readiness; Preschool Institution; Preparatory Classes; Mathematical Development; Linguistic Development

\section{Introduction}

Preschool education is the first level of education, in which children are educated in their families or in preschool institutions (ages 0 - 3 and ages 3 - 6) and preparatory grades (ages 5 6). As a result of a range of socio-economic factors, it still lacks a serious approach to this first level of the education. Preschool education in Kosovo has yet to take the place it deserves within the education system and our society as a whole. Regarding the overall involvement of children of our country, in institutionalized preschool education, statistics show the lowest involvement in the region. Advanced pedagogical and psychological studies show that the first six years of the child's life have a major impact in shaping the human personality.

It is necessary that children in this age are exposed to more diverse experiences of life, to promote emotional, social and intellectual development and maturity through the game. This will help the child to enter the world of school without sense of fear, distrust and inferiority (Brada, 1995).

This is what has led me to do a research on the effects of preschool education in preparing children for the first grade of primary school.

Extensive research has been done in the world, especially in the US, but not in our country about early childhood education forms and especially the impact of various forms of education in this age. My goal is to ascertain the value of institutional preschool education, and to influence on the decision of Kos- ovar parents in choosing the right form of the education of preschool children.

\section{Literature Review}

No doubt, it is very true that every beginning is difficult, but not prepared and well-planned ones. Starting something without being emotionally ready, without desire, without any information about the content, without being in favorable physical condition, will be the real challenge. If we talk about the six-year-olds who have just started the first grade, I guess we will have the same thought with the scholar researchers that the school readiness should be seriously considered.

According to Emilj Kamenov, human life has decisive moments, important events, which will always be kept in mind. One of these events starts definitely in the first grade of elementary school, which means a new beginning in the whole development. Depending on how the child will be prepared to start school, to a large extent, will depend on his success, not only during the first grade, but perhaps his success throughout the education and success in his lifetime (Kamenov, 1997).

In addition to preparing children for the first grade, it is very important the chronological aspect. There is an optimal age, when a child, or student, can achieve more success in the acquisition of knowledge, skills and habits. And, if you forced the pupil to learn before this time and age, when they still did not reach the maturity to learn, although they would make great 
efforts, however, the progress of their success would be much slower. Also, the teaching and learning that is offered to those students after reaching this age or optimal time may not be effective, since the time or interest to learn has passed (Dervodeli, 2010).

Although children of the same age have the same psycho-physical properties, they have distinctive features, based on which they differ from others. These are called individual psycho-physical properties (Deva-Zuna, 2003). From this observation, we can understand that not all children of the same calendar age can be equally ready to start the first grade. The role and importance of parents in the development and education of preschool children's is undeniable, taking into account the characteristics of children of this age, especially plasticity, sensitivity, their ability to understand quickly and their activity (Deva-Zuna, 2003). Role of the institutionalized preschool education in preparing children to learn the letters, reading and writing should be understood and addressed in the preparation of general preschool child, which includes, among others, senso-motoric education, psycho-social and intellectual education. Preparing preschoolers for recognition and learning of letters, reading and writing should not be seen as a special preparation of the "candidates" for the school. Such an approach would alter the child; would detach him from the joy and preschool life experiences (Mulla, 2011).

School readiness is more than just about children. School readiness, in the broadest sense, involves children, families, early environment, schools, and communities (NASBE, 1991). Children are not innately ready or not ready for school. Their skills and development are strongly influenced by their families and through their interactions with other people and environment before coming to school. Schools are also an important part of the readiness puzzle because different schools have different expectations about readiness. The same child, with the same strength and needs, can be considered ready in one school and not ready in another school. It is the school's responsibility to educate all children who are old enough to legally attend school, regardless of their skills (Maxwell \& Clifford, 2004). Generally, there are two different kinds of school readiness assessments: naturalistic assessments (sometimes referred to as informal or authentic) and standardized, norm-referenced assessments (sometimes referred to as formal). Naturalistic assessments include observations, work samples, and teacher checklists. Although both types of assessment are sometimes used for various purposes, the naturalistic type is most often used for the purpose of improving learning. Standardized, norm-referenced assessments follow a standard set of administration rules so that each child theoretically experiences the assessment similarly (for example, each person administering the test gives the same instructions (Maxwell \& Clifford, 2004).

When children reach at the 1 st grade, they need social, emotional, intellectual, and language skills to participate successfully. To prepare children for school, numerous initiatives have sprouted all over the country to make kindergarten and preschool programs available to all children. Most of these programs are designed for children aged three and beyond. Yet, it is during the first two years of life that early experience starts shaping the foundational learning structures of the brain (Lally, 2010).

It is known that starting the first grade to school is associated with a variety of phenomena, which require a parent engagement for dealing with them. But if the parent with his experi- ence affects the child, in scientific terms this is difficult because the parent is not "education specialist". It is more complicated when you consider the mathematics, where the terminology and its treatment are very different from the one parents learnt themselves. In this way, the goodwill of parents to help their children in mathematics may not be realized. It is a wonder when the parents "are more disadvantaged than children", although gradually this backlog is eliminated. However, parents need to "learn” (Rrapo \& Babamusa, 2001).

\section{Research Methodology}

Operational definitions: Preschool education includes children from birth to their enrollment in primary school. Readiness for the first grade: it is a broad term which includes intellectual maturity, social and emotional. Readiness is a scale in child development when he can learn easily, effectively and without emotional distress. It may not be a definitive point of development, because development is a continuous process throughout life. Furthermore, it is a condition that indicates that the child is ready to learn. Preschool institutions: can define buildings or homes that are built in a special way to provide preschool programs that meet the educational needs and develop the needs of the children to their enrollment in primary school. Preschool grades: Includes children aged 5 - 6 years old and is mainly part of the elementary school.

The aim of the research is to determine the level of readiness of children to start the first grade, with a focus on developing mathematical and linguistic. Hypothesis: The inclusion of preschool children in kindergartens has raised the level of mathematical and linguistic development of children up to the age of six, more than education preschool grades or families.

Research questions: How much are six year old children prepared in terms of mathematical development? How prepared are six year old children in terms of language development? Are kindergarten children more prepared than those who are educated in the family during preschool?

Methods: To determine the level of readiness of children for the first grade, evaluation research will be applied, and in order to compare the forms of education (family, kindergarten and preschool classes) comparative research will be applied. Instrument for assessing children's readiness for the first grade standardized questionnaire was used by the American Association "Brainline” author Joey Du Plooy. The questionnaire was translated and adapted to our circumstances.

The importance of research: This research is very important because it raises awareness of the importance of preschool age, not only to a good start in the first grade, but also in their later success at school. Research limitations-this research may have limitations as follows. When assessing children for the first grade, they are given only a possibility and can happen to a child in those moments not to be able to give answers and to perform as well as they can. Parents' responses can be subjective, when it is known that for each parent, his child is the "best one" or "smartest one", etc.

\section{Population and Sample}

The population of this research includes all children enrolled in the first grade in September 2011 in Kosovo. This population is numerically determined and according to statistics of Ministry of Education in the first grade all over Kosovo are 1395 classes with 30,665 children, 15,856 males and 14,809 females. 
Since this number is too large to be studied, then it was randomly selected a probability sample. This sample includes seven schools in different villages in Kosovo, three schools in three towns and five schools in five cities in Kosovo.

\section{Research Results and Discussion}

In this paper are presented results which show the level of mathematical and linguistic development of children who have started the first grade. In the following are presented some descriptive and inferential statistics by crosstabs and correlations. Results from Table 1, show that out of 455 children, 132 of them or $27.9 \%$, appear not ready in terms of linguistic development, 230 of them or $48.6 \%$ are quite ready and only 93 of them or $19.7 \%$, are very ready in terms of linguistic development. Regarding the mathematical development, 233 children or $49.3 \%$ are not ready, while 224 children or $47.4 \%$ of them are very ready.

As we can see from Table 2, the relationship between linguistic development and whether the child has been part of institutionalized preschool education was investigated through Pearson correlation. Tests are carried out in advance if the conditions of normal distribution and homogeneity are completed, and it was noted that there is a weak positive linear relationship but with statistical significance where $(r=.176, \mathrm{~N}=455, p$ $=.001)$.

From Table 3, there are results that show a big number of six-year-old children that were not ready for math, so 233 or $49.3 \%$ of them didn't fulfilled the request for math development. $47.4 \%$ of them were ready, very good, but this number

Table 1.

Linguistic development.

\begin{tabular}{cccccc}
\hline & & Frequency & Percent & $\begin{array}{c}\text { Valid } \\
\text { percent }\end{array}$ & $\begin{array}{c}\text { Cumulative } \\
\text { percent }\end{array}$ \\
\hline \multirow{4}{*}{ Valid } & Not ready & 132 & 27.9 & 29.0 & 29.0 \\
& Ready & 230 & 48.6 & 50.5 & 79.6 \\
& Very ready & 93 & 19.7 & 20.4 & 100.0 \\
& Total & 455 & 96.2 & 100.0 & \\
\multirow{2}{*}{ Missing } & System & 18 & 3.8 & & \\
& Total & 473 & 100.0 & & \\
\hline
\end{tabular}

Table 2.

Correlation between attendance to kindergarten and linguistic development.

\begin{tabular}{|c|c|c|c|}
\hline & & $\begin{array}{l}\text { Did the child went } \\
\text { to kindergarten }\end{array}$ & $\begin{array}{c}\text { Linguistic } \\
\text { development }\end{array}$ \\
\hline \multirow{3}{*}{$\begin{array}{l}\text { Did the child } \\
\text { went to } \\
\text { kindergarten }\end{array}$} & $\begin{array}{l}\text { Pearson } \\
\text { Correlation }\end{array}$ & 1 & $.176^{* *}$ \\
\hline & $\begin{array}{c}\text { Sig. } \\
\text { (2-tailed) }\end{array}$ & & .001 \\
\hline & $\mathrm{N}$ & 382 & 373 \\
\hline \multirow{3}{*}{$\begin{array}{c}\text { Linguistic } \\
\text { Development }\end{array}$} & $\begin{array}{l}\text { Pearson } \\
\text { Correlation }\end{array}$ & $.176^{* *}$ & 1 \\
\hline & $\begin{array}{c}\text { Sig. } \\
\text { (2-tailed) }\end{array}$ & .001 & \\
\hline & $\mathrm{N}$ & 373 & 455 \\
\hline
\end{tabular}

Note: ${ }^{* *}$ Correlation is significant at the .01 level (2-tailed). tells us that only half of children will start firs grade ready to learn mathematical concepts etc

The correlation between Attendance in the kindergarten and Math development is 0.109 . This is not that high, but the p-value (in the Sig. (2-tailed)) is .016. This is below .05 (for a $5 \%$ test) and thus is significant at the $5 \%$ level. Thus there is a relationship between the two variables. This can be seen at Table 4.

From the crosstabs bellow at the Table 5, we can see that only $17.3 \%$ from children who went to kindergarten can't count above 20 and $82.7 \%$ of them can do this. The same table shows that from children that didn't go to kindergarten, 32.9\% of them cannot count above 20, and only $67.1 \%$ can do this. Symmetric measures show that (Phi $=.162$ with Approx. Sig. .000). There is a significant relationship between attending the kindergarten

Table 3.

Math development.

\begin{tabular}{cccccc}
\hline & & $\begin{array}{c}\text { Fre- } \\
\text { quency }\end{array}$ & Percent & $\begin{array}{c}\text { Valid } \\
\text { percent }\end{array}$ & $\begin{array}{c}\text { Cumulative } \\
\text { percent }\end{array}$ \\
\cline { 2 - 6 } Valid & Not ready & 233 & 49.3 & 50.7 & 51.3 \\
& Ready very good & 224 & 47.4 & 48.7 & 100.0 \\
\multirow{4}{*}{ Missing } & Total & 460 & 97.3 & 100.0 & \\
& System & 13 & 2.7 & & \\
& Total & 473 & 100.0 & & \\
\hline
\end{tabular}

Table 4.

Correlation.

\begin{tabular}{cccc}
\hline & Pearson & $\begin{array}{c}\text { Did the child went } \\
\text { to kindergarten }\end{array}$ & $\begin{array}{c}\text { Math } \\
\text { development }\end{array}$ \\
\hline $\begin{array}{c}\text { Did the child } \\
\text { went to } \\
\text { kindergarten }\end{array}$ & $\begin{array}{c}\text { correlation } \\
\text { Sig. } \\
\text { (2-tailed) } \\
\text { N }\end{array}$ & 1 & $.109^{*}$ \\
& $\begin{array}{c}\text { Pearson } \\
\text { Math }\end{array}$ & 500 & .016 \\
correlation & $.109^{*}$ & 492 \\
Sig. \\
(2-tailed) \\
development
\end{tabular}

Note: *Correlation is significant at the .05 level (2-tailed).

Table 5.

Crosstab.

\begin{tabular}{ccccc}
\hline & & \multicolumn{2}{c}{ Counts above 20 } & \multirow{2}{*}{ Total } \\
\cline { 2 - 4 } & & Yes & No & \\
\hline Did the child went to & Yes & $32.9 \%$ & $67.1 \%$ & $100.0 \%$ \\
kindergarten & No & $17.3 \%$ & $82.7 \%$ & $100.0 \%$ \\
Total & & $28.0 \%$ & $72.0 \%$ & $100.0 \%$ \\
\hline \multicolumn{4}{c}{ Symmetric measures } \\
\hline \multirow{2}{*}{ Nominal by nominal } & Phi & .162 & .000 \\
& Cramer's V & .162 & .000 \\
\hline
\end{tabular}


and ability to count above 20 .

There are other examples from the measures that show the relevance of attending kindergarten through preschool age.

We can conclude that the level of readiness increases with participation of children in nursery education. This result supports the hypothesis given in the beginning of the study. Based on international literature review, it is noticed that institutionalized preschool education has a primary importance because this is a crucial age also for determining the level of intelligence.

\section{Recommendations}

- For a proper emotional, intellectual and social development of children, all parents are advised that preschool children should be sent to the kindergarten and pre-primary grades, until the preschool education becomes compulsory in our state.

- Leading education institutions are recommended to increase the number of kindergartens. Existing preschool institutions do not meet even the minimum needs of preschool children.

- Existing institutions, whether public or private, are advised to follow the rhythm of development of preschool children and meet their needs and interests, for optimized preparation for a good beginning of the firs grade.

- Educators are recommended to provide maximum support to preschool children for the free development of each individual capacity.

\section{REFERENCES}

Assembly of Kosovo (2006) Preschool Education Law. January 2006. http://www.handi-kos.org/trunk/modules/news/files/Ligji\%20per\%2 0edukim\%20parashkollor.pdf

Brada, R. (2001). Pedagogy of the family. Peja: Dukagjini publishing house.

Deva-Zuna, A. (2003). Education of the preschool child in the family.

Dervodeli, J. (2010). Differences between the success of the children that has been registered on time, before the time and after they were ready for the first grade. Prishtina: Author.

Lally, J. R. (2010). School Readiness Begins in Infancy. Phi Delta Kappan, 92, 17-21.

Kajtazi-Thaçi, A. (2008). The analyze of the preschool education in the State of Kosovo. Pristina.

http://www.masht-gov.net/advCms/documents/Analize_e_gj_se-tanis hme_ne_ed_parashk_ne_Kosove.pdf

Maxwell, K. L., \& Clifford, R. M. (2004). School readiness assessment. Young Children, 2004, 42-49.

Mulla, A. (2011). Role of Preschool Institutions in early childhood readiness at reading and writing development, Bulletin 1. Tirana: Planetarium University of Tirana.

National Association of State Boards of Education. (1991). Caring communities supporting young children and families. The Report of the National Task Force on School Readiness, Washington, DC: Distributed by ERIC Clearinghouse.

Rrapo, N., \& Babamusa, N. (2001). Child, parents and math. Tirana. http://www.see-educoop.net/education_in/pdf/femija_primdi_math-a lb-aln-t06.pdf

Veseli, A. (1999). Preschool pedagogy. Pristina: University of Pristina. 